\title{
Leukotriene Antagonists Attenuate Thromboxane-Inducible Pulmonary Hypertension
}

\author{
SCOTT J. SOIFER, MICHAEL D. SCHREIBER, AND MICHAEL A. HEYMANN \\ Cardiovascular Research Institute and the Departments of Pediatrics, Physiology, Obstetrics, Gynecology and \\ Reproductive Sciences, University of California San Francisco, San Francisco, California 94143
}

\begin{abstract}
Leukotrienes $C_{4}$ and $D_{4}$ and thromboxane $\mathrm{A}_{2}$ are potent vasoconstrictors that may mediate pulmonary vasoconstriction in many clinical situations. There is a complex interaction among leukotrienes and thromboxane $A_{2}$, because inhibition of thromboxane synthesis prevents some of the hemodynamic effects of exogenous leukotrienes. Similarly, if leukotrienes mediate thromboxane $A_{2-}$ induced pulmonary vasoconstriction, then leukotriene antagonists should attenuate the effects of a thromboxane $A_{2}$-mimetic such as U46619. First, dose response curves for the hemodynamic effects of $\mathrm{U} 46619$ were performed on seven spontaneously breathing newborn lambs. Then a putative leukotriene receptor antagonist, FPL57231, $1 \mathrm{mg}$ $\mathrm{kg} / \mathrm{min}$, or a putative leukotriene synthesis antagonist, U60257, $30 \mathrm{mg} / \mathrm{kg}$, was given before infusing U46619 (1 $\mu \mathrm{g} / \mathrm{kg} / \mathrm{min})$. U46619 caused significant dose-dependent increases in pulmonary and systemic arterial pressures $(p<$ $0.05)$ and significant dose-dependent decreases in cardiac output and heart rate $(p<0.05)$. A $1 \mu \mathrm{g} / \mathrm{kg} / \mathrm{min}$ infusion of U46619 increased pulmonary arterial pressure by $155.4 \% \pm 8.9$ and systemic arterial pressure by $8.9 \% \pm$ 7.7 and decreased cardiac output by $19.7 \% \pm 12.2$ and heart rate by $9.9 \% \pm 10.6$. FPL57231 attenuated the effects of U46619. U60257 had similar effects. Therefore, the hemodynamic effects of thromboxane $A_{2}$, an important mediator of the pulmonary vasoconstriction produced, for example, by group B streptococci and Escherichia coli, may be mediated by the secondary production of leukotrienes. (Pediatr Res 26: 83-87, 1989)
\end{abstract}

Metabolites of arachidonic acid may mediate the pulmonary vasoconstriction seen in utero $(1,2)$ and during alveolar hypoxia (3-6). They may also be important mediators of the hemodynamic changes occurring in the adult respiratory distress syndrome (7), endotoxic shock (8-14), and the syndrome of persistent pulmonary hypertension of the newborn (15). The most potent pulmonary vasoconstricting metabolites of arachidonic acid are the peptidoleukotrienes (leukotrienes $\mathrm{C}_{4}$ and $\mathrm{D}_{4}$ ) (1618), formed via the lipooxygenase pathway, and thromboxane $\mathrm{A}_{2}(8,10,11,13,14)$, formed via the cyclooxygenase pathway. There is a complex interaction among these leukotrienes and thromboxane $A_{2}$. To date, the evidence suggests that leukotriene $\mathrm{C}_{4}$ and $\mathrm{D}_{4}$ stimulate the production of thromboxane $\mathrm{A}_{2}(16,18-$ 21 ). These studies would imply that thromboxane $A_{2}$ is involved in leukotriene-induced pulmonary vasoconstriction. The pur-

Received June 17, 1988; accepted April 13, 1989

Correspondence and reprints Scott J. Soifer, M.D., M-646, University of California, San Francisco, CA 94143-0106.

Supported by Grants HL 35518 and HL 24056 from the National Heart, Lung and Blood Institute and by a Grant-in-Aid from the American Lung Association. pose of the present study was to investigate the other possibility: that thromboxane $A_{2}$ stimulates the production or release of leukotrienes. Because of the instability of thromboxane $A_{2}$ and the limited potency of its stable measurable metabolite, thromboxane $\mathrm{B}_{2}$, we used the specific thromboxane $\mathrm{A}_{2}$-mimetic, U46619 (Upjohn Co., Kalamazoo, MI) (22-29). In newborn lambs, after characterizing the pulmonary and systemic hemodynamic effects of U46619 by performing dose-response studies, we attempted to block or attenuate the hemodynamic response to U46619 using FPL57231, a putative leukotriene receptor antagonist (Fisons plc, Loughborough, England) $(2,5,16)$ and U60257, a putative leukotriene synthesis inhibitor (Upjohn) (1, $6,30-34)$

\section{MATERIALS AND METHODS}

Surgical Preparations. Under local anesthesia with $1 \%$ lidocaine hydrochloride, seven newborn lambs at 1 to $3 \mathrm{~d}$ of age had polyvinyl catheters placed into a hind leg artery and vein and advanced to the descending aorta and inferior vena cava, respectively. General anesthesia was then induced by having the lamb breathe a mixture of oxygen and halothane. The lamb was then intubated with a $4.5-\mathrm{mm}$ ID endotracheal tube and mechanically ventilated with a Harvard animal ventilator. Anesthesia was maintained with $1-2 \%$ halothane.

A left lateral thoracotomy was performed in the fourth intercostal space (35). Polyvinyl catheters were then placed into the internal thoracic artery and vein and advanced to the ascending aorta and right atrium, respectively. The pericardium was incised along the main pulmonary trunk. Teflon cannulae attached to polyvinyl catheters were inserted into the main pulmonary artery and left atrium. A precalibrated electromagnetic flow transducer (CC Instruments, Los Angeles, CA) was placed around the ascending aorta to measure cardiac output (left ventricular output minus coronary blood flow). A chest tube was placed into the pleural space. The thoracotomy incision was closed in layers. The catheters were filled with heparin, plugged, and, along with the transducer cable, brought to the skin, where they were protected in a pouch sewn to the lamb's flank. The lamb was weaned from mechanical ventilation, extubated, and, after recovery from anesthesia, returned to its mother. An intramuscular injection of $1 \mathrm{~mL}$ of penicillin $\mathrm{G}$ procaine and dihydrostreptomycin sulfate suspension was given daily. Three days were allowed for recovery.

Experimental Protocol. U46619 dose response. With the lamb spontaneously breathing and resting quietly in a sling, baseline measurements of the hemodynamic variables (pulmonary and systemic arterial pressures, left and right atrial pressures, heart rate, and cardiac output) and systemic arterial $\mathrm{pH}$ and blood gases were made (baseline). Doses of U46619 (0.1, 0.5, 1.0, and $2.0 \mu \mathrm{g} / \mathrm{mg} / \mathrm{min}$ ) were then infused for $15 \mathrm{~min}$ into the inferior vena cava. Each lamb received all doses; the order of doses was 
randomly chosen. The doses used were based on previous studies from our and other laboratories $(22,27-29,36)$.

The hemodynamic variables were measured continuously and the systemic arterial $\mathrm{pH}$ and blood gases were measured after 15 min at the steady state maximal response (U46619). A total of $20 \mathrm{~min}$ was allowed between infusions for recovery and return of the hemodynamic variables to baseline. Preliminary data showed that the response to U46619 was reproducible after waiting this time period. Also, there was no evidence for tachyphylaxis.

U46619 infusion during leukotriene antagonism. To determine the role of leukotrienes in producing the hemodynamic effects of U46619, either the putative leukotriene receptor antagonist, FPL57231, or the putative leukotriene synthesis inhibitor, U60257, was given before infusing U46619. The doses used were based on previous studies from our and other laboratories (1-3, $5,6,16,17)$. First, with the lamb spontaneously breathing and resting in a sling, baseline measurements of the hemodynamic variables and systemic arterial $\mathrm{pH}$ and blood gases were made (baseline 1). Then, U46619 (1 $\mu \mathrm{g} / \mathrm{kg} / \mathrm{min})$ was infused for 15 min and the effects recorded (U46619). After a 20-min recovery period, measurements were repeated (baseline 2). Then either FPL57231 or U60257, randomly assigned, was administered.

FPL57231 ( $1 \mathrm{mg} / \mathrm{kg} / \mathrm{min})$, a dose previously shown to prevent the hemodynamic effects of leukotrienes (17), was infused for 20 min. After 5 min of infusion, all measurements were repeated (FPL57231) and U46619 $(1 \mu \mathrm{g} / \mathrm{kg} / \mathrm{min})$ was then infused as the FPL57231 infusion continued. After 15 more min of infusion of both U46619 and FPL57231, the hemodynamic variables, sys- temic arterial $\mathrm{pH}$, and blood gases were measured (U46619+ FPL57231). Both infusions were then stopped.

U60257 (30 mg/kg), a dose previously shown to reverse hypoxia-induced pulmonary hypertension in newborn lambs (6) and to increase pulmonary blood flow in fetal lambs (1), was injected intravenously. Then $30 \mathrm{~min}$ after this injection, the measurements were repeated (U60257) and U46619 $(1 \mu \mathrm{g} / \mathrm{kg} /$ min) was then infused for $15 \mathrm{~min}$. The hemodynamic variables, systemic arterial pH, and blood gases were measured (U46619 + U60257). The U46619 infusion was then stopped. The two studies, using either FPL57231 or U60257, were performed 24 $\mathrm{h}$ apart.

Drug Preparation. All drugs were prepared immediately before use. U46619 in ethanol was stored at $-70^{\circ} \mathrm{C}$ and prepared by diluting the compound in $0.9 \%$ saline. FPL57231 was prepared as a $1 \%$ solution in sterile water. U60257 was stored at $-20^{\circ} \mathrm{C}$ and prepared by diluting the compound in $5 \mathrm{~mL}$ of $0.9 \%$ saline.

Measurements and Analyses. Pulmonary and systemic arterial and right and left atrial measures were measured with Statham Db23 pressure transducers. Mean pressures were obtained by electrical integration. Cardiac output (left ventricular output minus coronary blood flow) was measured on a Statham SP2202 flow meter. The flow transducers were calibrated in vitro using appropriate preformed molds and infusions of normal saline (37). The flow meters were adjusted to zero during diastole when aortic flow was assumed to be zero. Heart rate was triggered from the phasic systemic arterial pressure pulse wave. All hemodynamic variables were continuously recorded on a Beckman multichannel direct writing recorder (Beckman Instruments, Inc.,
A

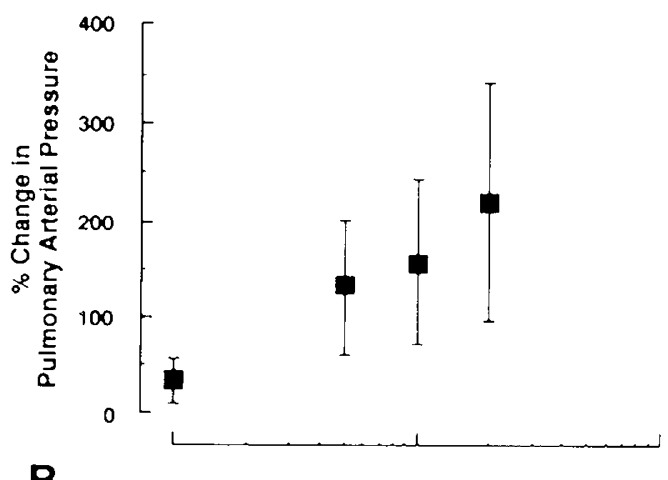

B

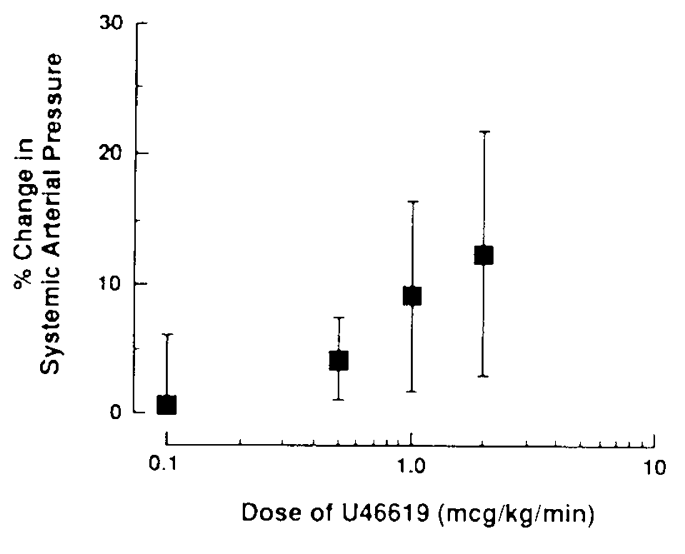

$\mathrm{N}=7 ;$ Mean \pm S.D.

Fig. 1. U46619, a thromboxane $\mathrm{A}_{2}$-mimetic, causes dose-dependent increases in $(A)$ pulmonary $[\mathrm{Y}=135.7(\mathrm{X})+167.6, r=0.65, p<0.05$, $\left.\mathrm{S}_{\mathrm{Y} \cdot \mathrm{X}}=78.5\right]$ and $(B)$ systemic $\left[\mathrm{Y}=8.8(\mathrm{X})+8.6, r=0.56, p<0.05, \mathrm{~S}_{\mathrm{Y}}\right.$ $\mathrm{x}=6.4 \mathrm{]}$ arterial pressures.
A Dose of $U 46619(\mathrm{mcg} / \mathrm{kg} / \mathrm{min})$
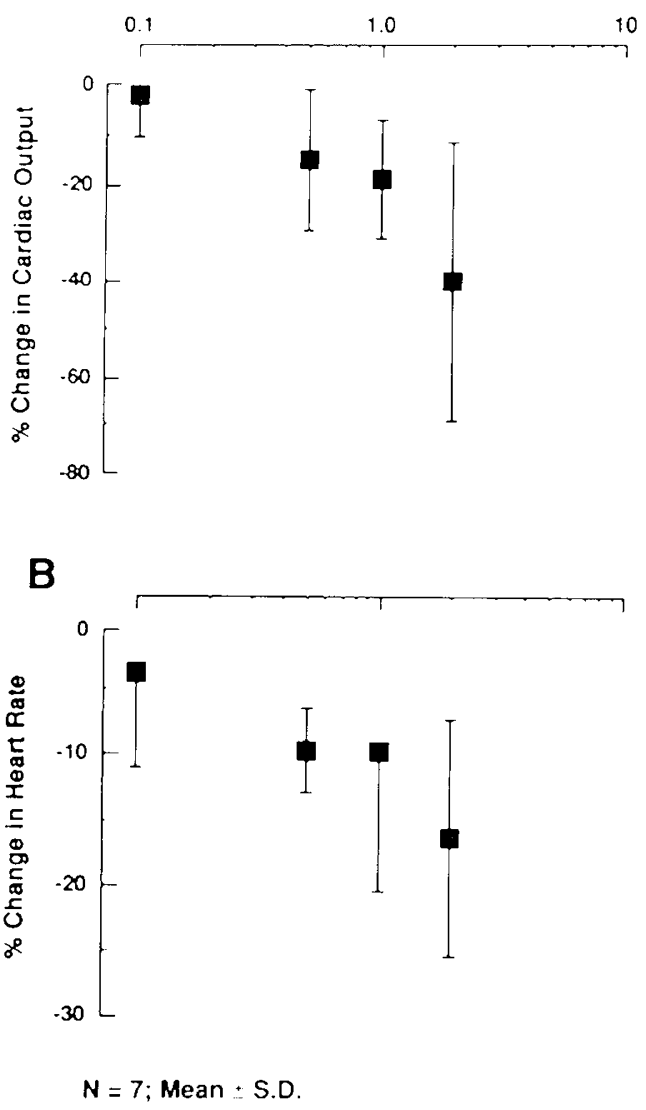

Fig. 2. U46619, a thromboxane $\mathrm{A}_{2}$-mimetic, causes dose-dependent decreases in $(A)$ cardiac output $[\mathrm{Y}=-26.3(\mathrm{X})-25.9, r=0.60, p<$ $\left.0.05, \mathrm{~S}_{\mathrm{Y}, \mathrm{X}}=17.3\right]$ and $(B)$ heart rate $[\mathrm{Y}=-8.5(\mathrm{X})-11.9, r=0.48, p$ $\left.<0.05, S_{Y \cdot X}=7.8\right]$. 
Table 1. Hemodynamic effects of infusions of U46619 in newborn lambs $(n=7$, mean $\pm S D)$

\begin{tabular}{|c|c|c|c|c|c|c|}
\hline \multirow{2}{*}{$\begin{array}{c}\text { Dose } \\
(\mu \mathrm{g} / \mathrm{kg} / \mathrm{min})\end{array}$} & \multicolumn{2}{|c|}{$\begin{array}{l}\text { Pulmonary arterial pressure } \\
\text { (mm Hg) }\end{array}$} & \multicolumn{2}{|c|}{$\begin{array}{l}\text { Systemic arterial pressure } \\
(\mathrm{mm} \mathrm{Hg})\end{array}$} & \multicolumn{2}{|c|}{ Cardiac output $(\mathrm{mL} / \mathrm{kg} / \mathrm{min})$} \\
\hline & Baseline & $\mathrm{U} 46619$ & Baseline & U46619 & Baseline & U46619 \\
\hline 0.5 & $17.3 \pm 3.9$ & $37.7 \pm 3.6^{*}$ & $75.4 \pm 11.3$ & $78.6 \pm 13.2$ & $227.9 \pm 47.6$ & $187.0 \pm 26.0^{*}$ \\
\hline 1.0 & $18.2 \pm 5.7$ & $42.5 \pm 5.3^{*}$ & $74.3 \pm 11.1$ & $80.7 \pm 12.2^{*}$ & $221.0 \pm 27.1$ & $177.6 \pm 35.5^{*}$ \\
\hline \multirow[t]{2}{*}{2.0} & $17.3 \pm 5.8$ & $49.2 \pm 2.5^{*}$ & $74.6 \pm 9.5$ & $83.3 \pm 10.3^{*}$ & $229.2 \pm 38.3$ & $131.0 \pm 60.3^{*}$ \\
\hline & \multicolumn{2}{|c|}{ Left atrial pressure $(\mathrm{mm} \mathrm{Hg})$} & \multicolumn{2}{|c|}{ Right atrial pressure (mm $\mathrm{Hg}$ ) } & \multicolumn{2}{|c|}{ Heart rate (beats/min) } \\
\hline 0.1 & $0.2 \pm 4.1$ & $1.2 \pm 5.0$ & $-0.1 \pm 2.7$ & $1.4 \pm 2.2$ & $220.3 \pm 26.3$ & $213.0 \pm 36.5$ \\
\hline 0.5 & $0.2 \pm 3.2$ & $1.8 \pm 4.2^{*}$ & $0.5 \pm 1.8$ & $0.9 \pm 2.6$ & $226.7 \pm 31.1$ & $205.7 \pm 32.8^{*}$ \\
\hline 1.0 & $0.7 \pm 4.1$ & $2.8 \pm 5.8$ & $0.4 \pm 2.4$ & $2.0 \pm 4.7$ & $225.9 \pm 31.1$ & $203.7 \pm 36.4^{*}$ \\
\hline 2.0 & $-0.9 \pm 3.4$ & $2.3 \pm 5.4^{*}$ & $-0.5 \pm 2.3$ & $2.5 \pm 3.5$ & $234.0 \pm 20.1$ & $196.5 \pm 28.0^{*}$ \\
\hline
\end{tabular}

$* p<0.05$ versus baseline.

Fullerton, CA). Systemic arterial $\mathrm{pH}$ and blood gases were measured at $39^{\circ} \mathrm{C}$ on a Corning $158 \mathrm{pH} /$ blood gas analyzer (Corning Glass Works, Corning, NY).

Means \pm SD were calculated for hemodynamic variables and systemic arterial $\mathrm{pH}$ and blood gases before (baseline) and during each infusion of U46619 at the maximum response (U46619) and compared by a paired $t$ test. The dose-dependent effects of U46619, compared as percent change from baseline values, were analyzed using linear regression analysis. The effects of FPL57231 and U60257 on the hemodynamic response to U46619 were compared using analysis of variance techniques and the Newman-Keuls test for multiple comparisons. A $p<$ 0.05 was considered statistically significant (38).

\section{RESULTS}

U46619 dose response. When plotted on semi-log paper and expressed as percent change from baseline values, U46619 produced dose-dependent increases in pulmonary arterial pressure and systemic arterial pressure and dose-dependent decreases in cardiac output and heart rate (Figs. 1 and 2). Absolute values are shown in Table 1. There was also a significant increase in left atrial pressure $(p<0.05)$. The maximum changes occurred by 1 $\mathrm{min}$ and lasted for the duration of the infusion of U46619. All hemodynamic variables returned to baseline values $20 \mathrm{~min}$ after the infusion was stopped. Infusion of drug vehicle had no hemodynamic effects. There were some minor changes in systemic arterial $\mathrm{pH}$ and blood gases (data not shown).

U46619 infusion during leukotriene antagonism. FPL57231 caused no change in baseline pulmonary and systemic arterial and left and right atrial pressures or systemic arterial $\mathrm{pH}$ and blood gases. It did increase cardiac output by $19 \%(p<0.05)$. FPL57231 blocked the increase in pulmonary arterial pressure produced by a $1 \mu \mathrm{g} / \mathrm{kg} / \mathrm{min}$ infusion of U46619 $(p<0.05)$ (Fig. 3). Similarly, U60257 caused no change in baseline hemodynamic variables or systemic arterial $\mathrm{pH}$ and blood gases. U60257 attenuated the increase in pulmonary arterial pressure produced by a $1 \mu \mathrm{g} / \mathrm{kg} / \mathrm{min}$ infusion of U46619 ( $p<0.05$ ) (Fig. 4).

\section{DISCUSSION}

The results of this study demonstrate that the thromboxane $\mathrm{A}_{2}$-mimetic, U46619, causes dose-dependent increases in pulmonary and systemic arterial pressures and dose-dependent decreases in cardiac output and heart rate in spontaneously breathing newborn lambs. These hemodynamic effects are attenuated by the putative leukotriene receptor antagonist, FPL57231, and the putative leukotriene synthesis inhibitor, U60257, suggesting that leukotrienes may mediate these effects.

Although U46619 is a chemical analogue of the endoperoxide $\mathrm{PGH}_{2}$, its biologic activity is identical to thromboxane $\mathrm{A}_{2}$ (2329). U46619, like thromboxane $A_{2}$, strongly contracts strips of
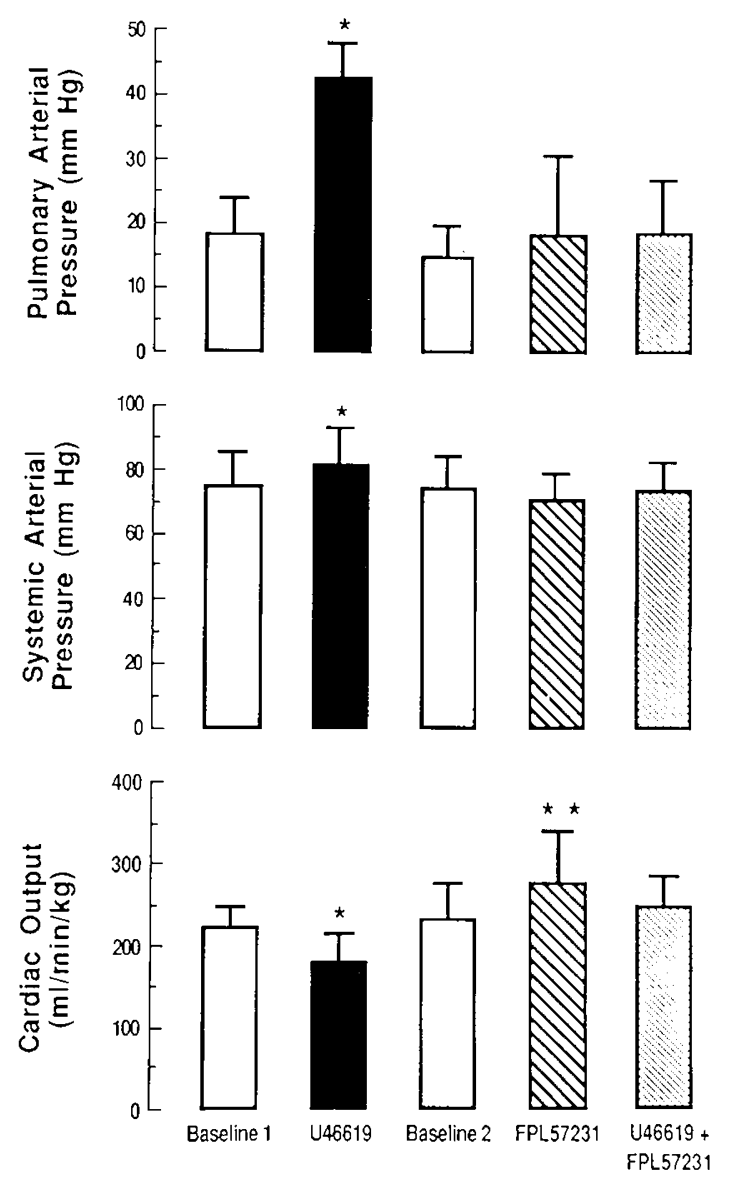

$\mathrm{N}=7$; Mean \pm S.D.; * vs Baseline $1 ; \star \star$ vs U46619 (ANOVA)

Fig. 3. FPL57231 attenuates the hemodynamic effects of U46619.

guinea pig lung, dog saphenous vein, and rabbit and rat aorta. It is a weak constrictor or is inactive on strips of guinea pig ileum and stomach, cat trachea, and cat and dog iris sphincter muscles (24-26, 29). Kadowitz and Hyman (28) have previously studied the hemodynamic effects of U46619 on anesthetized adult dogs. In their model, U46619 also increased pulmonary and systemic arterial pressures. However, cardiac output did not change significantly. The hemodynamic effects were blocked by a putative thromboxane $\mathrm{A}_{2}$ receptor antagonist. Assuming an average dog wt of $10 \mathrm{~kg}, 0.5 \mu \mathrm{g} / \mathrm{kg}$ injection of U46619 increased pulmonary arterial pressure by $118 \%$ and systemic arterial pressure by $15 \%$, compared to 130 and $4 \%$, respectively, in our lamb study (27). The difference in effect on cardiac output is most likely secondary 

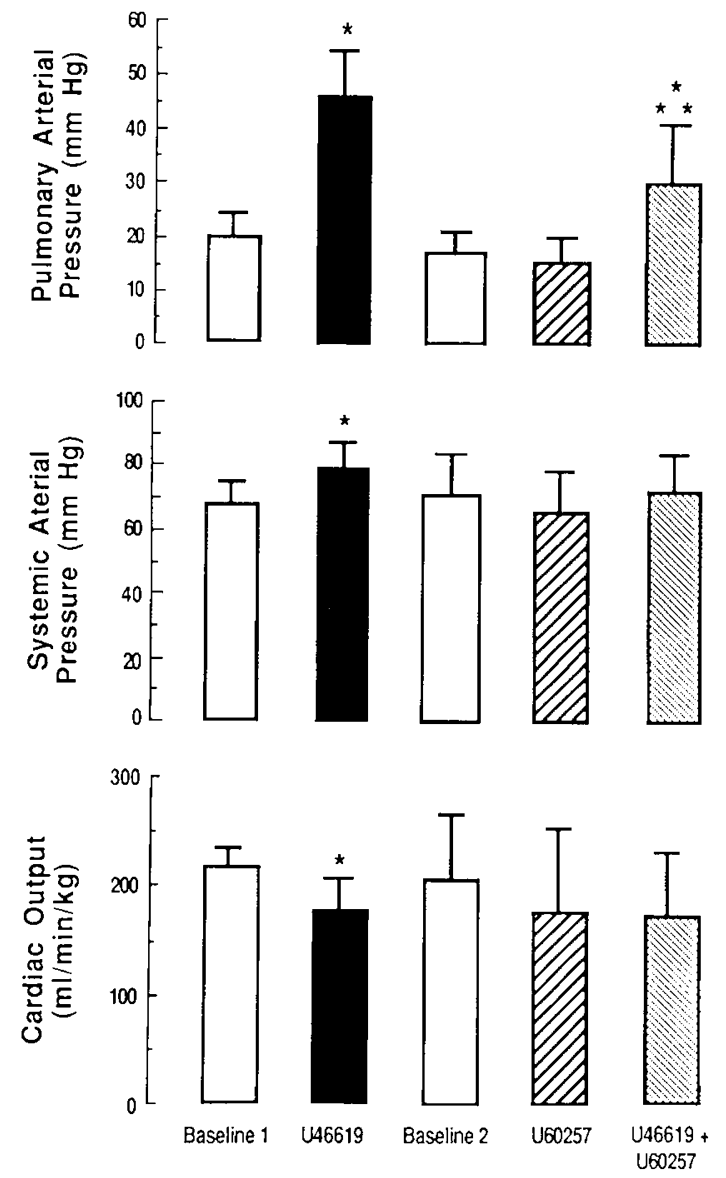

$\mathrm{N}=7$; Mean \pm S.D.; * vs Baseline $1 ; \star \star$ vs U46619 (ANOVA)

Fig. 4. U60257 attenuates the hemodynamic effects of U46619.

to differences in study design, because in anesthetized lambs, U46619 did not significantly change cardiac output (36).

Thromboxane $\mathrm{A}_{2}$ is an important mediator of the pulmonary hypertension caused by the infusion of endotoxin or live or heatkilled group B streptococci (8-14). Infusion of Escherichia coli endotoxin into lambs and sheep causes a marked early increase in pulmonary arterial pressure associated with an increase in plasma concentrations of thromboxane $B_{2}(8-10,12,39)$. Similar results have been produced by infusing live group $B$ streptococci into adult sheep and young piglets $(13,14)$. Administration of indomethacin, imidazole, or other inhibitors of thromboxane synthesis prevents the increase in both pulmonary arterial pressure and the serum concentration of thromboxane $B_{2}(8,10,11$, $13,14)$.

Other studies have suggested that thromboxane $A_{2}$ may also play a role in the pulmonary hypertension caused by leukotrienes. For example, in sensitized guinea pig lungs stimulated by leukotriene $C_{4}$, thromboxane $A_{2}$ production is increased (19). Similarly, leukotriene $\mathrm{C}_{4}$ and leukotriene $\mathrm{D}_{4}$ caused a dosedependent contraction of isolated perfused guinea pig lungs and an increase in thromboxane production. Both effects were blocked by imidazole, a thromboxane synthetase inhibitor (21). The hemodynamic and airway effects of leukotriene $C_{4}$ and $D_{4}$ have also been attenuated by inhibition of thromboxane synthesis $(16,18,20,28)$. It is not clear whether the increase in thromboxane is predominantly responsible for the effects of leukotrienes or simply acts as a method of bioamplification. The present study would indicate that this relationship is bidirectional.

Our study shows that the hemodynamic effects of a thromboxane $\mathrm{A}_{2}$-mimetic, $\mathrm{U} 46619$, can be blocked by putative leukotriene antagonists. This implies that thromboxane $\mathrm{A}_{2}$ causes an increase in the production and the release of leukotrienes. Alternatively, U46619 could be a leukotriene agonist. This is unlikely, because U46619 does not contract guinea pig ileum, a requirement for leukotrienes (25).

FPL57231 and FPL55712 are competitive leukotriene receptor antagonists (40). FPL57231 produces a similar degree of leukotriene antagonism as its parent compound, FPL55712, although it has little antiallergic effects (40). FPL57231 and FPL55712 completely block the hemodynamic effects of exogenously administered leukotrienes in newborn lambs (17) and piglets (41). In isolated perfused rat lungs, FPL55712 blocked the pulmonary hypertensive effects of leukotriene $\mathrm{C}_{4}$, but not of potassium or angiotensin II (30), although in neonatal piglets, it blocked the effects of leukotriene $\mathrm{C}_{4}$ and $\mathrm{D}_{4}$, but not of lysine vasopressin (41).

It is possible that FPL57231 blocked the hemodynamic effects of U46619 because it is a thromboxane receptor antagonist or because it has other nonspecific vasodilating effects. FPL57231 increases pulmonary blood flow in fetal lambs even in the presence of a thromboxane synthesis inhibitor $(2,41)$. Therefore, FPL57231 is not a thromboxane receptor antagonist. In some studies, FPL57231 has decreased vascular pressures and tended to increase cardiac output $(43,44)$, but not in others $(5,17)$. In pump-perfused fetal goat lungs, very large bolus doses of FPL57231 (to $10 \mathrm{mg} / \mathrm{kg}$ ) prevented the pulmonary pressor response to leukotriene $\mathrm{D}_{4}$ and lowered normal pulmonary vascular resistance (45). In this model, FPL57231 also blocked the pulmonary pressor response to phenylephrine $\mathrm{HCl}$ and $\mathrm{U} 46619$ (45). However, in the perfused rat lung, FPL55712 did not block the pulmonary pressor response to angiotensin II (30). In our study, FPL57231 did increase cardiac output without changing vascular pressures. During U46619 infusion, FPL57231 attenuated the hemodynamic effects.

Because FPL57231 may have nonspecific vasodilating effects (46), we also studied the effects of U60257, a putative leukotriene synthesis inhibitor, on the hemodynamic effects of U46619. U60257 inhibits leukotriene synthesis from human leukocytes, antigen-sensitized human lung and rat mononuclear cells at both the $5^{\prime}$ lipoxygenase and leukotriene $\mathrm{D}_{4}$ synthetase steps (31-34). Although U60257 is an analog of prostacyclin, it does not have any platelet antiaggregating effects $(33,34)$. The hemodynamic effects of $\mathrm{U} 60257$ are therefore likely not mediated by prostacyclin. In fetal lambs, U60257 increases pulmonary blood flow similarly to FPL57231. U60257 blocks hypoxic pulmonary vasoconstriction and leukotriene $\mathrm{C}_{4}$ production in isolated perfused rat lungs without effect on antiotensin II-induced pulmonary hypertension $(4,30)$. In our study, U60257 had no effect on baseline vascular pressure or cardiac output. During U46619 infusion, U60257 attenuated the hemodynamic effects. There was a small increase in pulmonary arterial pressure compared to U46619 infusion alone. FPL57231 did completely block the increase in pulmonary arterial pressure. This difference may be due to a time delay in achieving maximal $5^{\prime}$ lipoxygenase inhibition, which may take more than $30 \mathrm{~min}$ to be achieved (1). Because U60257, a putative leukotriene synthetase inhibitor and structurally unrelated to FPL57231, thromboxane $A_{2}$, or U46619, also attenuated the hemodynamic effects of U46619, it is likely that leukotrienes may mediate many of the effects of U46619.

In conclusion, our study demonstrates that U46619, a thromboxane $\mathrm{A}_{2}$-mimetic, is a potent pulmonary vasoconstrictor. In addition, the hemodynamic effects of U46619 and, presumably thromboxane $\mathrm{A}_{2}$, may be mediated in part through the production of leukotrienes.

Acknowledgments. The authors thank Randall Kikukawa for editorial assistance and Mary Hellgeth for technical assistance. We also thank Philip Sheard, M.Sc. of Fisons plc, Loughborough, England for generously supplying FPL57231 and Michael Bach, 
Ph.D., Upjohn Co., Kalamazoo, MI for generously supplying U60257.

\section{REFERENCES}

1. LeBidois J, Soifer SJ, Clyman RI, Heymann MA 1987 Piriprost: a putative leukotriene synthesis inhibitor increases pulmonary blood flow in fetal lambs. Pediatr Res 22:350-354

2. Soifer SJ, Loitz RD, Roman C, Heymann MA 1985 Leukotriene end-organ antagonists increase pulmonary blood flow in fetal lambs. Am J Physiol 249:H570-H576

3. Ahmed T, Oliver W Jr 1983 Does slow-reacting substance of anaphylaxis mediate hypoxic pulmonary vasoconstriction? Am Rev Respir Dis 127:566571

4. Morganroth ML, Stenmark KR, Zirrolli JA, Mauldin R, Mathias M, Reeves JT, Murphy RC, Voelkel NF 1984 Leukotriene $C_{4}$ production during hypoxic pulmonary vasoconstriction in isolated rat lungs. Prostaglandins 28:867-875

5. Schreiber MD, Heymann MA, Soifer SJ 1985 Leukotriene inhibition prevents and reverses hypoxic pulmonary vasoconstriction in newborn lambs. Pediatr Res 19:437-441

6. Soifer SJ, Schreiber MD, Frantz EG, Heymann MA 1986 Inhibition of leukotriene synthesis attenuates hypoxia-induced pulmonary vasoconstriction in newborn lambs. Pediatr Res 20:441 A(abstr)

7. Matthay MA, Eschenbacher WC, Goetzl EJ 1984 Elevated concentration of leukotriene $\mathrm{D}_{4}$ in the pulmonary edema fluid of patients with the adult respiratory distress syndrome. J Clin Immunol 4:479-483

8. Brigham KL, Meyrick B 1986 Endotoxin and lung injury. Am Rev Respir Dis 133:913-927

9. D'Orio V, Halleux J, Rodriguez LM, Wahlen C, Marcelle R 1986 Effects of Escherichia coli endotoxin on pulmonary vascular resistance in intact dogs. Crit Care Med 14:802-806

10. Hüttemeier PC, Watkins WD, Peterson MB, Zapol WM 1982 Acute pulmonary hypertension and lung thromboxane release after endotoxin infusion in normal and leukopenic sheep. Circ Res 50:688-694

11. Kubo K, Kobayashi T 1985 Effects of OKY-046, a selective thromboxane synthetase inhibitor, on endotoxin-induced lung injury in unanesthetized sheep. Am Rev Respir Dis 132:494-499

12. Pennington DG, Hyman AL, Jaques WE 1973 Pulmonary vascular response to endotoxin in intact dogs. Surgery 73:246-255

13. Rojas J, Larsson LE, Olgatree ML, Brigham KL, Stahlman MT 1983 Effects of cyclooxygenase inhibition on the response of Group B streptococcal toxin in sheep. Pediatr Res 17:107-110

14. Runkle B, Goldberg RN, Streitfeld MM, Clark MR, Buron E, Setzer ES, Bancalari E 1984 Cardiovascular changes in Group B streptococcal sepsis in the piglet: response to indomethacin and relationship to prostacyclin and thromboxane $\mathrm{A}_{2}$. Pediatr Res 18:874-878

15. Stenmark KR, James SL, Voelkel NF, Toews WH, Reeves JT, Murphy RC 1983 Leukotriene $C_{4}$ and $D_{4}$ in neonates with hypoxemia and pulmonary hypertension. N Engl J Med 309:77-80

16. Ahmed T, Marchette B, Wanner A, Yerger L 1985 Direct and indirect effects of leukotriene $\mathrm{D}_{4}$ on the pulmonary and systemic circulations. Am Rev Respir Dis 131:554-558

17. Schreiber MD, Heymann MA, Soifer SJ 1987 The differential effects of leukotriene $\mathrm{C}_{4}$ and $\mathrm{D}_{4}$ on the pulmonary and systemic circulations in newborn lambs. Pediatr Res 21:176-182

18. Yokachi K, Olley PM, Sideris E, Hamilton F, Huhtanen D, Coceani F 1982 Leukotriene $\mathrm{D}_{4}$ : a potent vasoconstrictor of the pulmonary and systemic circulations in the newborn lamb. In: Samuelsson B, Paoletti R (eds) Leukotrienes and other Lipoxygenase Products. Raven Press, New York, pp 211-214

19. Folco G, Hansson G, Gaström E 1981 Leukotriene $C_{4}$ stimulates $T_{X A_{2}}$ formation in isolated sensitized guinea pig lungs. Biochem Pharmacol 30:2491-2493

20. Omini C, Folco GC, Vigano T, Rossoni G, Brunelli G, Berti F 1981 Leukotriene $\mathrm{C}_{4}$ induces generation of $\mathrm{PGI}_{2}$ and $\mathrm{TXA}_{2}$ in guinea-pig in vivo. Pharmacol Res Commun 13:633-640

21. Piper PJ, Samhoun MN 1982 Stimulation of arachidonic acid metabolism and generation of thromboxane $A_{2}$ by leukotrienes $B_{4}, C_{4}$ and $D_{4}$ in guinea-pig lung in vitro. $\mathrm{Br} \mathrm{J}$ Pharmacol 77:267-275

22. Bowers RE, Ellis EF, Brigham KL, Oates JA 1979 Effects of prostaglandin cyclic endoperoxides on the lung circulation of unanesthetized sheep. J Clin Invest 63:131-137
23. Bundy GL 1975 The synthesis of prostaglandin endoperoxide analogs. Tetrahedron Lett 24:1957-1960

24. Bunting S, Moncada S, Vane JR 1976 The effects of prostaglandin endoperoxides and thromboxane $A_{2}$ on strips of rabbit coeliac artery and certain other smooth muscle preparations. Br J Pharmacol 462P-463P

25. Coleman RA, Humphrey PPA, Kennedy I, Levy GP, Lumley P 1981 Comparison of the actions of $U-46619$, a prostaglandin $\mathrm{H}_{2}$-analogue, with those of prostaglandin $\mathrm{H}_{2}$ and thromboxane $\mathrm{A}_{2}$ on some isolated smooth muscle preparations. Br J Pharmacol 73:773-778

26. Coleman RA, Humphrey PPA, Kennedy I, Levy GP, Lumley P 1979 U-46619, a selective thromboxane $\mathrm{A}_{2}$-like agonist? $\mathrm{Br} \mathrm{J}$ Pharmacol 68:127P-128P

27. Kadowitz PJ, Hyman AL 1977 Influence of a prostaglandin endoperoxide analogue on the canine pulmonary vascular bed. Circ Res 40:282-287

28. Kadowitz PJ, Hyman AL 1984 Analysis of responses to leukotriene $\mathrm{D}_{4}$ in the pulmonary vascular bed. Circ Res 55:707-717

29. Wilson $\mathrm{NH}$, Jones RL 1985 Prostaglandin endoperoxide and thromboxane $\mathrm{A}_{2}$ analogs. In: Pike JE, Morton DR (eds) Advances in Prostaglandin, Thromboxane, and Leukotriene Research, Vol 14. Raven Press, New York, pp $393-425$

30. Morganroth ML, Reeves JT, Mathias M, Murphy RC, Voelkel NF 1984 Leukotriene synthesis and receptor blockers block hypoxic pulmonary vasoconstriction. J Appl Physiol 56:1340-1346

31. Bach MK, Bowman BJ, Brashler JR, Fitzpatrick FA, Griffin RL, Johnson HG, Major NJ, McGuire JC, McNee ML, Richard IM, Smith HW, Smith RJ, Speziale SC, Sun FF 1985 Piriprost: a selective inhibitor of leukotriene synthesis. In: Hayaishi $\mathrm{O}$, Yamamoto $\mathrm{S}$ (eds) Advances in Prostaglandin Thromboxane, and Other Leukotriene Research, Vol 15. Raven Press, New York, pp 225-227

32. Bach MK, Brashler JR 1985 Studies with inhibitors of sufidopeptide leukotriene synthesis. In: Lefer AM, McGee MH (eds) Progress in Clinical and Biological Research. Alan Russ, Inc., New York, pp 85-89

33. Bach MK, Brashler JR, Fitzpatrick FA, Griffin RL, Iden SS, Johnson HG McNee ML, McGuire JC, Smith HW, Smith RJ, Sun FF, Wasserman MA 1983 In vivo and in vitro actions of a new selective inhibitor of leukotriene $\mathrm{C}$ and D synthesis. In: Samuelsson B, Paoletti R, Ramwell P (eds) Advances in Prostaglandin, Thromboxane, and Leukotriene Research, Vol 11. Raven Press, New York, pp 39-44

34. Bach MK, Brashler JR, Smith HW, Fitzpatrick FA, Sun FF, McGuire JC 1982 6,9-deepoxy-6,9-(phenylimino)-delta ${ }^{6.8}$-prostaglandin $I_{1}$, (U-60,257), a new inhibitor of leukotriene $C$ and D synthesis: in vitro studies. Prostaglandins 23:759-771

35. Sidi D, Kuipers JGR, Heymann MA, Rudolph AM 1982 Recovery of cardiovascular function in newborn lambs after thoracotomy. Pediatr Res 16: 705-710

36. Schreiber MD, Soifer SJ 1988 Respiratory alkalosis attenuates thromboxaneinduced pulmonary hypertension. Crit Care Med 16:1225-1228

37. Rudolph AM, Heymann MA 1980 Methods for studying the circulation of the fetus in utero. In: Nathanielsz PSW (ed) Animal Models in Fetal Medicine (I). Elsevier/North-Holland Biomedical Press, Amsterdam, pp 1-57

38. Zar JH 1974 Biostatistical Analysis. Prentice-Hall, Inc., Englewood Cliffs, NJ

39. Cartwright D, Soifer SJ, Mauray F, Clyman RI 1983 Endotoxin produces acute pulmonary hypertension and thromboxane elevation in the newborn lamb. Pediatr Res 17:1317(abstr)

40. Sheard P, Holroyde MC, Ghelani AM, Bantick JR, Lee TB 1982 Antagonists of SRS-A and leukotrienes. In: Samuelsson B, Paoletti R (eds) Leukotrienes and Other Lipoxygenase Products. Raven Press, New York, pp 229-235

41. Leffler CW, Mitchell JA, Green RS 1984 Cardiovascular effects of leukotrienes in neonatal piglets. Circ Res 55:780-787

42. Clozel M, Clyman RI, Soifer SJ, Heymann MA 1985 Thromboxane is not responsible for the high pulmonary vascular resistance in fetal lambs. Pediatr Res 19:1254-1257

43. Kulik TJ, Schutjer RK, Howland DF, Lock JE 1985 Pulmonary and systemic vascular effects of SRS-A blockade in conscious lambs. Am J Physiol 249:H968-H973

44. Goldberg RN, Sugihara C Ahmed T, DeCudermus BD, Banios P, Setzer ES Bancalari E 1985 Influence of an antagonist of slow reacting substance of anaphylaxis on the cardiovascular manifestations of hypoxia in piglets. Pediatr Res 19:1201-1208

45. Gause GE, Baker R, Cassin S 1988 Specificity of FPL57231 for leukotriene $D_{4}$ receptor in fetal pulmonary circulation. Am J Physiol 254:H120-H125

46. Coceani F, Olley IM 1988 Eicosanoids in the fetal and transitional pulmonary circulation. Chest 99:1125-1175 